\title{
Extrinsic factors influencing the bid/no-bid decision of construction contracting firms: Impact of firm size and experience
}

\author{
Ahsen Maqsoom (Main Author) \\ COMSATS University, Islamabad, Wah Campus, Department of Civil Engineering \\ Wah Cantt 47040 (Pakistan) \\ ahsen.maqsoom@ciitwah.edu.pk

\section{Hassan Ashraf} \\ COMSATS University, Islamabad, Wah Campus, Department of Civil Engineering \\ Wah Cantt 47040 (Pakistan) \\ drhassanashraf@ciitwah.edu.pk
}

\section{Rafiq Muhammad Choudhry (Corresponding Author)}

Al Imam Mohammad Ibn Saud Islamic University, Department of Civil Engineering Riyadh 11432 (Kingdom of Saudi Arabia)

rchoudhry@imamu.edu.sa

\section{Sufian Younas Khan}

COMSATS University, Islamabad, Wah Campus, Department of Management Sciences Wah Cantt 47040 (Pakistan)

sufiancomsats@gmail.com

\section{Muhammad Dawood}

National University of Sciences and Technology, School of Civil Engineering

Islamabad 44000 (Pakistan)

dawood917431@gmail.com

\section{Adeel Tariq}

National University of Sciences and Technology, School of Business Management Islamabad 44000 (Pakistan)

adeel.tariq@nbs.nust.edu.pk

Manuscript Code: 1573

Date of Acceptance/Reception: 20.04.2020/21.08.2019

DOI: 10.7764/RDLC.19.1.146-158

\begin{abstract}
Construction contracting firms (CCFs) are functioning in a highly volatile and competitive industrial environment making it imperative to bid for the projects that can produce the most return and market share. The decision making process to bid or not is based on various factors that vary from project to project and firm to firm. The aim of this work is to analyze the impact of firm size and experience on extrinsic factors influencing the $\mathrm{bid} / \mathrm{no}$-bid decision for construction projects. The questionnaire was pilot tested and designed in three parts. The final questionnaire was sent to 300 CCFs registered with Pakistan Engineering Council (PEC) and respondents were asked to rate the factors on a Likert scale. Out of 300 questionnaires, 167 completed responses are returned representing a response rate of 56\%. The collected data are then analyzed using MannWhitney $\mathrm{U}$ test through Statistical Package for Social Sciences (SPSS). Findings show the various degrees of differences between small and large, and young and mature CCFs with regard to factors influencing the bid/no-bid decision. Small firms need to overcome increasing market value and number of competitors in the market. They need to develop relationship with government officials in order to secure their bids. Mature firms need to review the payment practices of clients, politician pressure and business level of the client before entering into the bid. Availability of required material and skilled labor are of prime importance for the mature firms' success.
\end{abstract}

Keywords: Bid/no-bid decision, construction contracting firms, developing countries, firm experience, firm size.

Globally, the construction industry has continued to play a critical role in economies of both developed and developing nations (Zhao et al., 2014). The developing countries' construction contracting firms (CCFs) are on the rise and are becoming important global players (Low et al., 2020). Developing countries' CCFs are playing an important role in the worldwide economy, and are nowadays open to different challenges as they need to operate in risky 
political conditions and markets (Korkmaz \& Messner, 2008). Although these challenges carry new opportunities for firms to access new clients in the country, but at the same time, firms also need to counter challenges like new project environment, political conditions, local laws for procurement, new competitors and different quality demands of the clients (Ren et al., 2012; Zawawi et al., 2016).

To survive in a competitive construction industry, it is extremely imperative for a firm to secure tenders and produce a profit (Egemen \& Mohamed, 2007). There are two ways for a construction firm to obtain the job i.e. they can negotiate with the client or participate in competitive bidding to win the project (Maqsoom et al., 2018; Shash, 1993). Scholars argue that construction firms need to make a critical decision of participating in the bid or not, once an invitation is received (El-Mashaleh, 2013; Ma, 2011; Li et al., 2020). Wanous et al. (2003) found that winning the bid is extremely challenging especially in today's competitive construction markets. The most used technique in the construction market to avail a bid is competitive bidding (Fu et al., 2002). Under the competitive bidding technique, contractors face large number of problems. Hence, the decision of actually participating in the bid is one of the first and most crucial steps that need to be taken ( $\mathrm{Ma}, 2011)$, and involves a process of gathering information from disparate different sources (Bageis \& Fortune, 2009).

Pakistan as an emerging economy, is gradually becoming an important economic force in Asia because of its booming service sector and thriving small and medium enterprises (SMEs) (Maqsoom \& Charoenngam, 2014; Ndubisi \& Iftikhar, 2012). However, currently it is suffering from COVID 19, inflation and power crisis that adversely impact the construction industry (Maqsoom et al., 2020; Di Gregorio et al., 2008). Focusing on the country's stability, World Bank indicated a political stability index of as -2.49 , and Heritage Foundation gave an economic stability index of 44(Hill, 2008). As construction and infrastructure development is a key source for enhancing the economy and controlling the unemployment rate in any region, projects undertaken by construction firms are of extreme importance (Korkmaz \& Messner, 2008). The construction industry has faced problems in many large projects, for example, Allama Iqbal International Airport (AlIAP) and Tarbela Dam extension project had faced time and cost overruns mainly due to incompetent firms won the projects (Ahmad et al., 2018; Razzaq et al., 2018; Shabbar et al., 2017; Ullah et al., 2016). Another example is of Neelum Jehlum Hydropower Project that has gone around seven times of its initial depicted cost because of an incompetent firm secured the bid by quoting lower rates (Ahmad et al., 2018; Razzaq et al., 2018; Shabbar et al., 2017; Ullah et al., 2016). Further, New Islamabad International Airport has faced time overrun of a year due to the inability of the winning firm to complete the project within its time constraints (Ahmad et al., 2018; Razzaq et al., 2018; Shabbar et al., 2017; Ullah et al., 2016).

The bidding decision is a complex process that is affected by numerous external factors (Chou et al., 2013). Choosing not to bid on a prospective project results in losing an opportunity to make a substantial profit, whereas entering into bid may improve the strength of a contractor in the industry and gain positive relationships with the client (Jarkas et al., 2014). Bidding for unsubstantial projects can result in huge losses that include the consumption of resources as well as time that might have been invested in more profitable projects, ultimately resulting in financial failure of the firm (Egemen \& Mohamed, 2005). Surveys by previous scholars have identified some of the important factors in the bid/no-bid decision making (Li et al., 2020; Shokri-Ghasabeh \& Chileshe, 2016) but little consensus is found on optimal or specific approach regarding the decision to bid. Enshassi et al. (2010) observed that the tendency to bid increases with the size of firm, however, another found the opposite that propensity to bid and win a project decreases with the growth in company size (Krasnokutskaya \& Seim, 2011). Large construction firms in Saudi Arabia, for instance, displayed greater tendency to bidding than small construction firms (Shash \& Abdul-Hadi, 1993). The same conclusion is derived for Northern Cyprus and Turkish contractors (Egemen \& Mohamed, 2007). In addition, few researchers (Bageis \& Fortune, 2009) found that tendency to bid increases with the experience of construction firms, whereas Krasnokutskaya and Seim (2011) found the converse. For instance, longer experienced contractors prefer large-sized projects, while the less experienced contractors prefer small-sized projects (Enshassi et al., 2010; Nirab, 2007). Nonetheless, wide-ranging thoughts are evident from literature with little consensus on specific factors influencing the bid/no-bid decision for construction projects. It is difficult to fully understand bid/no-bid decision for construction projects, for example, the existence of an association between extrinsic factors vis-à-vis CCF size and experience (Bageis \& Fortune, 2009; Chua \& Li, 2000; Li et al., 2020). A firm generally arrives at a bid decision only after a complex reasoning process that is influenced greatly by the firm size and its previous experience (Chua \& Li, 2000; Ma, 2011).

The objective of this research is to evaluate the extrinsic factors including market, politics, client and region related aspects that influence the CCF's bid/no-bid decision for construction projects. Specifically, the current research analyses differences in the bid decision of CCFs with respect to the firm size and experience. The findings of this study provide novel insight to the bid/no-bid decision making literature with emphasis on clients and stakeholders' obligations where these is scarcity of literature related to the association between influencing factors, firm size and industrial experience. Further, the current study includes variables related to the politics that have been neglected in 
the previous studies (Bageis \& Fortune, 2009) in addition to the previous factors, thus making the current study unique in its examination for the bid/no-bid decision for construction projects.

According to the objective of the study, following research questions are proposed (see Figure 1):

RQ1. What are the market related factors that influence the bid/no-bid decision of CCFs of varied sizes and experience?

$R Q 2$. What are the politics related factors that influence the bid/no-bid decision of CCFs of varied sizes and experience?

$R Q 3$. What are the client related factors that influence the bid/no-bid decision of CCFs of varied sizes and experience? $R Q 4$. What are the region related factors that influence the bid/no-bid decision of CCFs of varied sizes and experience?

\section{Literature review}

There are two crucial decisions need to be made during the tendering process i.e. (1) decision to bid or not to bid, and (2) decision based on bid price. Friedman (1956) was the first person who carried research on the bid price, decision to bid and mark-up stage studies. Later, Gates (1967) used the same theme of research to produce his own work. From 1990s to the present day, various researches have been conducted on the bid decision making for construction projects.

Nonetheless, there is large volume of literature available regarding the extrinsic and intrinsic factors affecting the bid/no-bid decision for construction projects (Chua \& Li, 2000; Egemen \& Mohamed, 2007; Lowe \& Parvar, 2004; Shokri-Ghasabeh \& Chileshe, 2016). The current study focuses on the extrinsic factors influencing the bid/no-bid decision for construction projects with emphasis on firm size and experience. Extrinsic factors are defined as factors related to the external environment i.e. competition in the market and region and factors related to the politics, government and client history (Chua \& Li, 2000; Jarkas et al., 2014). Nirab (2007) studied 94 characteristics relating to the bidding decisions and classified them into three main categories, namely firm related factors, project related factors and market related factors. Similarly, Wanous et al. (2003) developed a simple parametric model to explain the bid/no-bid decision in the construction industry in Syria. Skitmore (2002) explained a number of factors that why contractors prefer to go for or back out from a particular bidding procedure. These factors included number and quality of bids successfully procured, strengths of the bidding process, levels of projected profit levels and the costs of bidding process. Ahmad (1990) determined five important factors that affect the bid/no bid decisions in USA that are need for work, historic benefits, type of job, owner's reputation and degree of hazards. Similarly, Odusote \& Fellows (1992) identified 42 factors that affect the bid/no bid decision of contractors in UK. Out of these 42 factors, they ranked the top five to be client's ability to pay, type of work, profitability, client's satisfaction and good relationship. Shokri-Ghasabeh and Chileshe (2016) identified four factors to be the most critical during bid/no-bid decision; these factors included client financial capability, project risk, project future benefits and profitability, and number of competitors in the market.

Egemen \& Mohamed (2007) assigned one of the main factors contributing in the bidding decisions as external market involving the strategic related knowledge of the market. Sonmez \& Sözgen (2017) stated the general principles upon which the bidding behavior of a contractor depends upon, and they categorized the market condition as the primitive factor in bidding process. Nirab (2007) while working on the study in the Gaza Strip identified the market related factors as being pivotal in the bidding techniques. Bageis et al. (2019) concluded market value as one of the important factors affecting the bidding decisions of CCFs in Saudi Arabia. Dulaimi and Shan (2002) found availability of other projects as critical in the bid mark-up decisions of CCFs in Singapore. Enshassi et al. (2010) ranked number of competitors in the market as one of the most important external factors influencing the bid/no-bid decisions of contractors in the Palestinian construction industry.

Scholars identified in their studies that the CCFs work consist of general environment factors such as politics and laws as well as competition factors such as finance, labor, suppliers, contractors and clients (Bageis et al., 2019; Newcombe et al., 1990). Similarly, Akintoye \& Skitmore (1990) stated that because of use of competitive bidding to award contracts, a CCF's survival strongly depends on its ability to work with different bidding situations. Various economic, social and political situations dictate to the number of construction firms registered and the degree of competition for construction works is vital. Other studies have shown that political trends, market potential, and technological changes affects the determination of mark-up during the bidding decisions (Dulaimi \& Shan, 2002). Mohanty (1992) discovered that in some geographical locations such as India, the political angle and family pressure influences the 
bidding decision. Enshassi et al. (2010) identified the stability of political conditions during construction among the top three factors that affect the bidding decisions of the Palestinian construction contractors.

The client policies are determined by pursuits such as their advertisement characteristics, tendering systems and reputation that influence the bid/ no-bid decision (Shokri-Ghasabeh \& Chileshe, 2016). Enshassi et al. (2010) identified that reputation and financial capability of the clients are critical factors influencing the bid/ no-bid decision of CCFs in the Palestinian and Gaza Strip construction industry. Similarly, while referring to the basis of CCF bidding decisions, Odusote \& Fellows (1992), summed up their findings stating that the reputation and previous experience of the client with the architect/engineer is a factor of prime importance in bidding decisions. Shash (1993) indicated client identity as one of the most important factor influencing the bidding decisions of the CCF. Chua and Li (2000) concluded that delay or shortage on payment habit of client can deeply influence the bidding decisions of CCFs. Bageis et al. (2019) expanded their research upon the client characteristics in terms of the bidding choice and found out that the client's attitude played significant role in the CCF's decision to bid. Client's experience, transparency and reputation are studied by various other researchers (Straub \&Van Mossel, 2007) and are identified as factors of prime importance in construction. Other researchers have found that the bid evaluation method of the client holds significant importance in the bid/ no bid decision of CCFs (Maqsoom et al., 2020; Wanous et al., 2003).

Regional stability and the condition of market greatly influence the bidding behaviors of the contractors (Enshassi et al., 2010; Sonmez \& Sözgen, 2017). CCF's bidding decisions are staunchly emphasized upon the external conditions and number of competitors in the region, their strengths and their stability. Odusote \& Fellows (1992) reflected that in a CCF, the contracts are undertaken depending upon the environmental competitiveness and regional coherence. Hwang \& Kim (2016) value the location of a project related to a particular region in terms of its stability and market competitiveness as a primitive factor of the bidding process. Enshassi et al. (2010) proposed that the availability of raw materials in the area and stability of the region are decisive factors influencing the bid/no-bid decision of contractors in the Palestinian construction industry. Odusote \& Fellows (1992) emphasized upon the location of the project as significant in bidding decisions. The availability of skilled labor in the region is seen as an imperial factor in bidding decisions of CCFs (Bageis et al., 2019). Dulaimi \& Shan (2002) identified the availability of equipment and other projects in the region as important factors in the Singaporean CCFs during their bidding decisions.

All of the above researches have valuably contributed to the bidding decision literature. Nonetheless, a comprehensive model, which not only considers the project conditions but also includes the regional strategic considerations, take into account the viewpoint of clients, differentiate among varied sizes and experiences of CCFs and considers political factors present in developing countries will be of great value. In this regard, a comprehensive conceptual framework is drawn based on above theoretical knowledge and is presented in Figure 1.

Figure 1. Conceptual Framework for Bid / No-Bid Decision of CCFs (Source: Self-Generated).

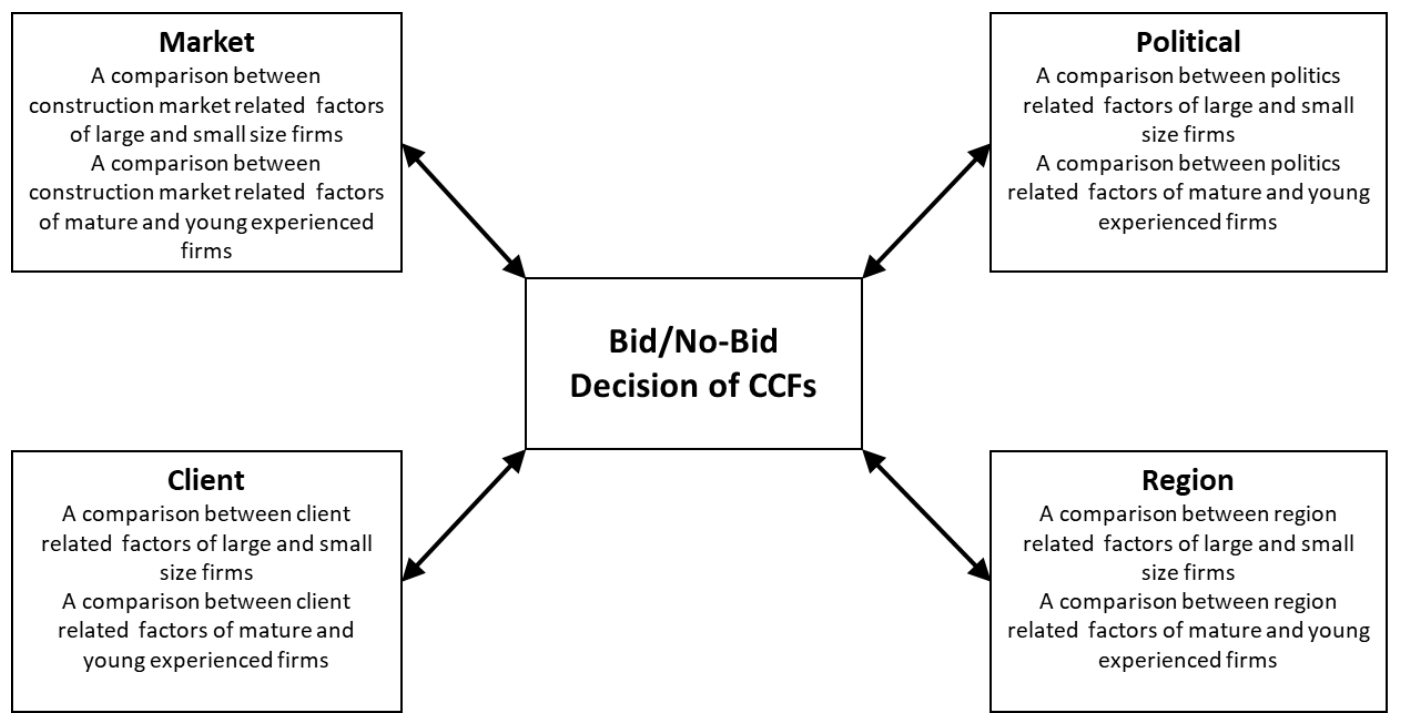


The current study is conducted in several stages with the first stage being the development and verification of a questionnaire. In light of the literature review, deep insight is acquired into the construction of a questionnaire that has the ability to capture imperative information to convert into meaningful results. The present study divided the questionnaire into three sections; the first section acquired general demographic information of the participants. The second section asked the information about the project and participant company. The third section is designed to assess the effect of different extrinsic factors on the bid/no-bid decisions of CCFs. The factors are classified as market related factors, politics related factors, client related factors and region related factors. The third section embraced scales adapted from the previous validated studies conducted by scholars to measure extrinsic factors influencing the bid/no-bid decision of firms (Bageis \& Fortune, 2009; Egemen \& Mohamed, 2007; Enshassi et al., 2010; Jarkas et al., 2014; Shash \& Abdul-Hadi, 1993). For the pilot testing, interviews are conducted with two general managers and five project managers working in different firms. Necessary adjustments are made in the questionnaire based on the suggestions provided by the respondents during the pilot study. Political factors have not been examined so far in the previous researches related to bid/no-bid decision of firms; therefore, they were included in the questionnaire based on the strong recommendation from the pilot test participants. The feedback from the pilot testing improved the readability and quality of the questionnaire. Additionally, the purpose of pilot test was to examine the feasibility and establish the validity of the research instrument.

Once the questionnaire is finalized, data collection took place using the survey approach. This research used the purposive sampling method for the data collection. The target population was the CCFs working in Federal area of Islamabad and Punjab province. The list of CCFs is obtained from Pakistan Engineering Council (PEC), a body that register all the construction-contracting firms. The questionnaire is sent to 300 CCFs registered with PEC through post or directly at their companies by the researchers. Respondent were asked to rate the factors from 1 to 5 ; with " 1 : strongly disagree", "2: disagree", "3: neutral”, "4: agree”, “5: strongly agree". Out of 300 questionnaires, 167 completed responses are returned representing a response rate of 56\%. Therefore, the sample was 167 CCF who participated in the research. No responses are collected from the remaining 133 firms due to their unwillingness to respond. The characteristics of the responding organizations are illustrated in Table 1.

\begin{tabular}{lcc}
\multicolumn{3}{c}{ Table 1. Responding organizations characteristics (Source: Questionnaire survey). } \\
\hline Characteristics & Frequency & Percentage \\
\hline Respondent's designation & & \\
Chief Executive Officer / Managing Director & 17 & 10 \\
Director / Chairman / Head & 45 & 27 \\
General Manager / Project Manager & 40 & 24 \\
Assistant Project Manager & 65 & 39 \\
Firm's specialization & & \\
Civil & 80 & 48 \\
Building & 47 & 28 \\
Electrical and mechanical & 26 & 16 \\
Other & 14 & 08 \\
Firm's experience & & \\
<5 years & 31 & 19 \\
6-10 years & 45 & 27 \\
11-15 years & 50 & 30 \\
$>15$ years & 41 & 24 \\
Number of employees in the firm & & \\
S100 employees & 45 & 27 \\
101-500 employees & 51 & 30 \\
501-1000 employees & 39 & 24 \\
$>1000$ employees & 32 & 19 \\
\hline
\end{tabular}

After collecting the responses, the researchers divided the sample into large vs small firms and mature vs young firm's categories according to firm size and industrial experience. There are different classifications for firm size and experience worldwide, which can vary by country, sector or region. For example, large firms are characterized as having more than 250 or 300 employees; similarly, mature firms are seen as having experience more than 5 or 10 years (Abdul-Aziz et al., 2013; Maqsoom \& Charoenngam, 2014; Maqsoom et al., 2019). In this research large firms are 
classified as having more than 250 employees and mature firms having experience 10 or more years in the construction industry (Abdul-Aziz et al., 2013).

The data obtained from the respondents are analyzed using the Statistical Package for Social Sciences (SPSS) Version 25 for Windows. In the beginning, the Shapiro-Wilk test is utilized to examine the normality of the data. The results showed that the data are not normally distributed, necessitating the use of a non-parametric test for the comparison between the groups. Therefore, non-parametric Mann-Whitney $U$ test is used to compare the scores given by firms of varied sizes and industrial experiences. Various scholars (Abdul-Aziz et al., 2013; Dulaimi \& Shan, 2002; Maqsoom \& Charoenngam, 2014) have used the same approach to test the significant differences among the CCFs.

\section{Results}

The results obtained from the survey show the presence of some significant differences between CCFs of varied sizes and experiences for bid-no-bid decision. Only the factors that recorded statistically significant differences ( $p$ value $<0.1$ ) between small and large or young and mature firms are presented in this section.

\section{Market Related Factors}

The first phase of analysis is linked to the market related factors influencing the bid/no-bid decision of CCFs. The Table 2 provides the results of market related factors that influence the bid/no-bid decision of CCFs with respect to size and experience. In terms of firm size, two variables are considered more important by small firms than large firms: market value (mean rank $=70.00$ for large firms and mean rank $=87.85$ for small firms, with $p$-value 0.043 ) and number of competitors in the market (mean rank $=62.19$ for large firms, and mean rank $=89.99$ for small firms, with $p$-value 0.002). Similarly, in terms of experience, there is significant difference regarding market related factors in young and mature firms. Two factors are considered more important by young firms than mature firms: availability of similar type of project in the market (mean rank $=80.02$ for mature firms and mean rank $=92.80$ for young firms, with $p$ value 0.099 ) and number of competitors in the market (mean rank= 78.16 for mature firms and mean rank= 96.91 for young firms, with $p$-value 0.016$)$.

Table 2. Market related factors influencing the bid/no-bid decision vis-à-vis CCF size and experience (Source: Analysis of the Survey).

\begin{tabular}{|c|c|c|c|c|c|c|}
\hline \multirow[t]{2}{*}{ Market related factors } & \multicolumn{3}{|c|}{ Mean rank for size } & \multicolumn{3}{|c|}{ Mean rank for experience } \\
\hline & $\begin{array}{l}\text { Large } \\
\text { firms }\end{array}$ & $\begin{array}{l}\text { Small } \\
\text { firms }\end{array}$ & $\begin{array}{l}\text { Significant } \\
\text { (2-tailed) }\end{array}$ & $\begin{array}{l}\text { Mature } \\
\text { firms }\end{array}$ & $\begin{array}{l}\text { Young } \\
\text { firms }\end{array}$ & $\begin{array}{c}\text { Significant } \\
\text { (2-tailed) }\end{array}$ \\
\hline $\begin{array}{l}\text { Taxes and other financial } \\
\text { requirements on tender }\end{array}$ & 83.46 & 84.15 & 0.938 & 82.15 & 88.09 & 0.453 \\
\hline Market value & 70.00 & 87.85 & $0.043 * *$ & 80.06 & 92.72 & 0.106 \\
\hline $\begin{array}{l}\text { Quantity of overall projects in } \\
\text { the market (no of projects) }\end{array}$ & 74.47 & 86.62 & 0.170 & 85.55 & 80.58 & 0.528 \\
\hline $\begin{array}{l}\text { Availability of similar type of } \\
\text { project in the market }\end{array}$ & 75.54 & 86.60 & 0.167 & 80.02 & 92.80 & $0.099 * * *$ \\
\hline $\begin{array}{l}\text { Number of competitors in the } \\
\text { market }\end{array}$ & 62.19 & 89.99 & $0.002 *$ & 78.16 & 96.91 & $0.016 * *$ \\
\hline
\end{tabular}

\section{Politics Related Factors}

The second phase of analysis is associated to the politics related factors influencing the bid/no-bid decision of CCFs. Table 3 shows the results of political factors that affect the bid/no-bid decision of CCFs with respect to size and experience.

In terms of firm size, two variables are considered as more important by small firms than large firms including relationship with government (mean rank $=67.26$ for large firms, and mean rank $=88.60$ for small firms, with $p$-value 0.016 ) and public acceptance to projects (mean rank= 67.85 for large firms, and mean rank= 86.62 for small firm, with $p$-value 0.031 ). In terms of experience, contrariwise, there is little difference regarding politics related factors in young and mature firms because there is only one factor, which is considered more important by mature firms than young 
firms i.e. government pressure during bidding (mean rank= 89.98 for mature firms and mean rank=70.78 for young firms, with $p$-value of 0.014).

Table 3. Politics related factors influencing the bid/no-bid decision vis-à-vis CCF size and experience (Source: Survey Analysis).

\begin{tabular}{|c|c|c|c|c|c|c|}
\hline \multirow[t]{2}{*}{ Politics related factors } & \multicolumn{3}{|c|}{ Mean rank for size } & \multicolumn{3}{|c|}{ Mean rank for experience } \\
\hline & $\begin{array}{l}\text { Large } \\
\text { firms }\end{array}$ & $\begin{array}{l}\text { Small } \\
\text { firms }\end{array}$ & $\begin{array}{l}\text { Significant } \\
\text { (2-tailed) }\end{array}$ & $\begin{array}{l}\text { Mature } \\
\text { firms }\end{array}$ & $\begin{array}{l}\text { Young } \\
\text { firms }\end{array}$ & $\begin{array}{c}\text { Significant } \\
\text { (2-tailed) }\end{array}$ \\
\hline $\begin{array}{l}\text { Politician reference for the gaining } \\
\text { of the project }\end{array}$ & 76.36 & 86.10 & 0.269 & 79.80 & 93.30 & 0.383 \\
\hline $\begin{array}{l}\text { Political conditions while } \\
\text { construction }\end{array}$ & 79.47 & 85.24 & 0.509 & 84.93 & 81.93 & 0.700 \\
\hline $\begin{array}{l}\text { Government pressure during } \\
\text { bidding }\end{array}$ & 79.51 & 85.23 & 0.517 & 89.98 & 70.78 & $0.014^{*}$ \\
\hline Relationship with government & 67.26 & 88.60 & $0.016^{*}$ & 86.80 & 77.82 & 0.256 \\
\hline $\begin{array}{l}\text { Interference from the opposition } \\
\text { parties }\end{array}$ & 77.89 & 83.80 & 0.498 & 83.41 & 85.31 & 0.809 \\
\hline Public acceptance to projects & 67.85 & 86.62 & $0.031^{*}$ & 84.54 & 82.81 & 0.825 \\
\hline Change in government policies & 79.74 & 83.28 & 0.685 & 82.63 & 87.03 & 0.576 \\
\hline
\end{tabular}

$* P \leq 0.05$

\section{Client Related Factors}

The third phase of analysis is connected to the client related factors influencing the bid/no-bid decision of CCFs. Table 4 provides the results of client related factors that affect the bid/no-bid decision of CCFs with respect to size and experience.

Table 4. Client related factors influencing the bid/no-bid decision vis-à-vis CCF size and experience (Source: Analysis of the Survey).

\begin{tabular}{|c|c|c|c|c|c|c|}
\hline \multirow[t]{2}{*}{ Client related factors } & \multicolumn{3}{|c|}{ Mean rank for size } & \multicolumn{3}{|c|}{ Mean rank for experience } \\
\hline & $\begin{array}{l}\text { Large } \\
\text { firms }\end{array}$ & $\begin{array}{l}\text { Small } \\
\text { firms }\end{array}$ & $\begin{array}{l}\text { Significant } \\
\text { (2-tailed) }\end{array}$ & $\begin{array}{l}\text { Mature } \\
\text { firms }\end{array}$ & $\begin{array}{l}\text { Young } \\
\text { firms }\end{array}$ & $\begin{array}{l}\text { Significant } \\
\text { (2-tailed) }\end{array}$ \\
\hline History of the client & 87.88 & 82.94 & 0.576 & 91.88 & 66.58 & $0.001^{*}$ \\
\hline $\begin{array}{l}\text { Current financial condition of the } \\
\text { client }\end{array}$ & 72.53 & 87.15 & $0.095 * *$ & 84.45 & 83.00 & 0.852 \\
\hline Client attitude & 87.78 & 82.96 & 0.587 & 85.26 & 81.21 & 0.607 \\
\hline Politicians pressure on the client & 89.60 & 82.46 & 0.421 & 88.15 & 74.82 & $0.090 * *$ \\
\hline $\begin{array}{l}\text { Method of bid evaluation of the } \\
\text { client }\end{array}$ & 82.64 & 84.37 & 0.845 & 81.42 & 89.71 & 0.293 \\
\hline Business level of the client & 93.63 & 81.35 & 0.166 & 88.45 & 74.16 & $0.070 * *$ \\
\hline $\begin{array}{l}\text { Project duration provided by the } \\
\text { client }\end{array}$ & 72.29 & 87.22 & $0.090 * *$ & 84.89 & 82.04 & 0.715 \\
\hline
\end{tabular}

In terms of firm size, two variables are considered more important by small firms than large firms. They include current financial condition of the client (mean rank $=87.15$ for small firms, and mean rank $=72.53$ for large firms, with $p$-value 0.095 ), and project duration provided by the client (mean rank $=87.22$ for small firms and mean rank= 72.29 for large firms, with $p$-value 0.090). In terms of experience, significant differences are observed between young and mature firms regarding client related factors. In this context, three factors are considered more important by mature firms than young firms. They are history of the client (mean rank $=91.88$ for mature firms and mean rank $=66.58$ for young firms, with $p$-value 0.001 ), politician's pressure on the client (mean rank $=88.15$ for mature firms and mean 
rank $=74.82$ for young firms, with $p$-value 0.090), and business level of the client (mean rank= 88.45 for mature firms and mean rank= 74.16 for young firms, with $p$-value 0.070 ).

\section{Region Related Factors}

The fourth phase of analysis is connected to the region related factors influencing the bid/no-bid decision of CCFs. Table 5 indicates the results of region related factors that impact the bid/no-bid decision of CCFs with respect to size and experience.

Table 5. Region related factors influencing the bid/no-bid decision vis-à-vis CCF size and experience (Source: Survey Analysis).

\begin{tabular}{|c|c|c|c|c|c|c|}
\hline \multirow[b]{2}{*}{ Region related factors } & \multicolumn{3}{|c|}{ Mean rank for size } & \multicolumn{3}{|c|}{ Mean rank for experience } \\
\hline & $\begin{array}{l}\text { Large } \\
\text { firms }\end{array}$ & $\begin{array}{l}\text { Small } \\
\text { firms }\end{array}$ & $\begin{array}{c}\text { Significant } \\
\text { (2-tailed) }\end{array}$ & $\begin{array}{l}\text { Mature } \\
\text { firms }\end{array}$ & $\begin{array}{l}\text { Young } \\
\text { firms }\end{array}$ & $\begin{array}{l}\text { Significant } \\
\text { (2-tailed) }\end{array}$ \\
\hline $\begin{array}{l}\text { Availability of required material in } \\
\text { the region }\end{array}$ & 82.69 & 84.36 & 0.643 & 89.73 & 71.34 & $0.020^{*}$ \\
\hline Availability of skilled labor & 96.86 & 80.47 & 0.252 & 89.66 & 71.48 & $0.020^{*}$ \\
\hline $\begin{array}{l}\text { Number of projects started in the } \\
\text { region }\end{array}$ & 93.57 & 81.82 & 0.851 & 87.53 & 76.18 & 0.151 \\
\hline Stability of the political situation & 89.33 & 82.53 & $0.062 * *$ & 87.09 & 77.16 & 0.208 \\
\hline $\begin{array}{l}\text { Availability of equipment in the } \\
\text { region }\end{array}$ & 80.78 & 84.89 & 0.170 & 82.25 & 87.87 & 0.476 \\
\hline $\begin{array}{l}\text { Availability of unskilled labor in the } \\
\text { region }\end{array}$ & 91.94 & 81.37 & 0.444 & 86.13 & 79.28 & 0.383 \\
\hline
\end{tabular}

In terms of size, only one variable is considered as more important by large firms than small firms in region related factors i.e. stability of the political situation (mean rank= 89.33 for large firms, and mean rank= 82.53 for small firms, with $p$-value 0.062 ).On the other hand, in terms of experience there is significant difference observed between young and mature firms because there are two factors, which are considered more important by mature firms than the young firms. One factor is availability of required material in the region (mean rank $=89.73$ for mature firms, and mean rank = 71.34 for young firms, with $p$-value 0.020 ) and the other factor is availability of skilled labor (mean rank= 89.66 for mature firms, and mean rank= 71.48 for young firms, with $p$-value 0.020 ).

Discussion

Results of the current study are presented in the previous section shown in Table 2 to Table 5. Discussion is provided in this section especially on the significant factors. The findings are compared with previous studies for their implication in the construction industry.

During the first phase, three significant factors related to market are determined that influence the bid/no-bid decision of CCFs of varied sizes and experience. A change in the construction market, even one of infinitesimal value can have major effects on the smaller CCFs since these firms are producing a small quantity of business due to their limited human capital and other resources. In the situation of an increased 'market value', the chance of the wining a bid for a small firm is decreased due to entrance of numerous competitors and clients having a greater variety of choices. On the other hand, if the 'market value' is decreasing then large firms have more advantages than that of the small firms as small firms are unable to compete with larger firms due to limited experience and recognition of reputation in the market specifically if the 'market value' is negative (Staniewski et al., 2016).

Young firms consider 'availability of similar type of project in the market' more important as compared to large firms. Young firms believe that if there are more similar types of projects in the market, they have a greater chance to win the project because they have more experience with that specific type of project and at the same time these similar projects increases their annual revenue and their experience (Krasnokutskaya \& Seim, 2011; Shokri-Ghasabeh \& Chileshe, 2016).

'Number of the competitors in the market' is considered more important factor by small firms as compared to the large firms. Small firms have less equipment and managerial staff to overcome the weak points of their firm so they believe that if the 'numbers of competitors in the market' are more then there is a decreased chance of winning a 
tender (Bustos-Salvagno, 2015; Oyeyipo et al., 2016). This factor is also more important for the young firms as compared to the mature firms as young firms believe if numerous competitors are participating in the industry, clients have a greater pool of firms to choose from, which gives firms with a greater reputation an upper hand and minimizes their chances of winning a project.

During the second phase, three significant factors related to politics are determined that influence the bid/no-bid decision of CCFs of varied sizes and experience. Mature firms have lots of experience and they had built a significant reputation in the industry. Every mature firm competes for mega projects to acquire a large profit and for developing a long-term relationship with the government but numerous mature firms experience "government pressure during bidding' because a mega project is awarded to the firm with a strong relationship with the present government (Bageis et al., 2019; Bageis \& Fortune, 2009). Nonetheless, numerous mature firms are discouraged from bidding due to fear of rejection.

Small firms consider the 'relationship with the government' more important factor as compared to large firms. They attempt to develop long-term relationships with every government in power. Small firms have less finance, experience and reputation as compared to large firms. Due to this disparity in resources smaller firms believe that if they have a good relationship with the government, their cost overrun and time overrun in public projects are tolerated by the authorities to some extent (Heravi \& Mohammadian, 2020; Jarkas et al., 2014). This factor is imperative for larger firms but comparable less to smaller firms. Larger firms have robust relationships with a number of politicians in addition to a strong reputation in the market and they are not discouraged from competing in the market due to governmental factors.

'Public acceptance of projects' is considered more important factor by small firms as compared to the large firms. Small firms are well aware of the fact that to compete in the construction industry, they have to acquire projects that have public support in order to increase their chances of acquiring more projects in the future. On the other hand, public outcry and opposition to a large project acquired by a smaller firm face greater issue of acceptance to the project especially if there are aspects of shady business dealings. Due to their smaller capacity, small firms do not have the budget to build stakeholder relationships with the public or develop public relationship programs. This inability stretches to government levels and smaller firms refrain from participating in bids of mega projects that face the opposition of the public (Enshassi et al., 2010; Nirab, 2007).

During the third phase, five significant factors related to clients are determined that influence the bid/no-bid decision of CCFs of varied sizes and experience. Clients, whether they are from the public or private sectors need to make cash payments to CCFs on time. 'History of the client (payment in the past project)' is an imperative factor for mature firms. Mature firms usually take larger projects to make more profit and develop a portfolio that is extensive for marketing purposes. Larger projects are costly and more cash is needed in circulation for efficient output, and prompt payment habit of the client is more crucial for mature firms than it is for young firms. If client is not habitual of paying on time, there is a greater risk for project delay or failure (Egemen \& Mohamed, 2007; Shokri-Ghasabeh \& Chileshe, 2016).

'Current financial condition of the client' is considered more important factor by the small firms as compared to large firms because small firms cannot take huge risks and are afraid that the client would not clear their bills on time so they would be unable to start a new project due to the limited finance. The result is similar to the findings of ElMashaleh (2013) who concluded that "client financial capabilities" are the highest ranked variables. Large firms have more capital than that of small firms and the profit made by large firms is more than that of small one (ShokriGhasabeh \& Chileshe, 2016). Small firms want that client should have more liquidity.

According to the current findings, 'politician's pressure on a client' is more important factor for mature firms as compared to young firms. Politics is an influential factor that is critical in order to secure projects. The construction sector is significantly influenced by politics and greatly susceptible to political pressures (Razzaq et al., 2018). Mature companies usually bid on larger projects to make more profit, and politician's pressure on the client can be a cause of various unexpected losses. It is important for mature firms to consider this factor whereas young firms normally bid for smaller projects, which eliminates the need for excessive political maneuvering and favors.

"Business level of the client" is considered more important factor by mature firms than young firms. Business level is classified as small, medium and large business level based on profit or revenue generated through projects. As the mature firms want to make more profits by gaining larger projects, they definitely prefer higher business level than medium or small business level. In contrast, young firms need projects despite of looking at business level of the client to gain fame in construction market and profit (Krasnokutskaya \& Seim, 2011).

'Project duration provided by the client' is very important to consider while bidding. According to the results, project duration given by the client is more important factor for small firms compared to large firms. Small firms do not have much experienced staff, equipment and managerial staff; also, they are not well familiar about the different site 
conditions, weather conditions, geological conditions, and uncertain risks as compared to the large firms. To overcome these uncertainties, enough time given to complete the project is much more important for small firms than large firms (Bageis \& Fortune, 2009).

During the fourth phase, three significant factors related to region are determined that influence the bid/no-bid decision of CCFs of varied sizes and experience. 'The availability of required materials in the region' is considered more important by mature firms than that of young firms. This is because these firms are experienced and well aware of the time and money spent on carrying materials from one place to another. Mature firms want to have as much profit as possible out of every project so it is important for them that the required material need to be procured near the construction site (Krasnokutskaya \& Seim, 2011).

'Availability of skilled labor' is marked more important by the mature firms as compared to young firms. This is because transporting skilled labor from headquarters to the site is difficult and expensive as there are costs for food, accommodation and transportation. Hence, mature firms attempt to hire skilled labor from places close to the construction site so that they can minimize expenses (Bageis et al., 2019; Krasnokutskaya \& Seim, 2011).

Large firms rated 'stability of the political situation in the region' is more important than that of small firms. They are well aware of the fact that if the political situations in the region of project are not favorable then taking the whole crew there and work would be highly risky, which can lead to severe losses in terms of both man-power and resources they are going to use on site (Maqsoom et al., 2019). As large firms move with more crew and equipment as compared to smaller firms, they face the chance of a higher degree of loss and hence, give this factor more importance than that of small firms.

To summarize, significant differences have been observed in the extrinsic factors influencing the bid/no-bid decision of CCFs vis-à-vis their size and experience. Market related factors that influence the bid/no-bid decision of CCFs of varied sizes and experience include 'market value', 'availability of similar type of projects in the market', and 'number of competitors in the market'. Politics related factors that influence the bid/no-bid decision of CCFs of varied sizes and experience include 'government pressure during bidding', 'relationship with government', and 'public acceptance of projects'. Client related factors that influence the bid/no-bid decision of CCFs of varied sizes and experience include 'history of the client (payment in the past project)', 'current financial condition of the client', 'politicians pressure on the client', 'business level of the client' and 'project duration provided by the client'. Region related factors that influence the bid/no-bid decision of CCFs of varied sizes and experience include 'availability of required material in the region', 'availability of skilled labor' and 'stability of the political situation in the region'. The significant differences in these 14 extrinsic factors influencing the bid/no-bid decision of CCFs are shown in Table 6.

Table 6. Significant extrinsic factors influencing the bid/no-bid decision vis-à-vis CCF size and experience (Source: Results from Table 2 to Table 5).

\begin{tabular}{|c|c|c|c|c|}
\hline \multirow[b]{2}{*}{ Extrinsic factors } & \multicolumn{2}{|c|}{ CCF size } & \multicolumn{2}{|c|}{ CCF experience } \\
\hline & $\begin{array}{l}\text { Large } \\
\text { firms }\end{array}$ & $\begin{array}{l}\text { Small } \\
\text { firms }\end{array}$ & $\begin{array}{c}\text { Mature } \\
\text { firms }\end{array}$ & $\begin{array}{c}\text { Young } \\
\text { firms }\end{array}$ \\
\hline \multicolumn{5}{|l|}{ Market related factors } \\
\hline Market value & $x$ & $\checkmark$ & - & - \\
\hline Availability of similar type of projects in the market & - & - & $x$ & $\checkmark$ \\
\hline Number of competitors in the market & $x$ & $\checkmark$ & $x$ & $\checkmark$ \\
\hline \multicolumn{5}{|l|}{ Politics related factors } \\
\hline Government pressure during bidding & - & - & $\checkmark$ & $x$ \\
\hline Relationship with government & $x$ & $\checkmark$ & - & - \\
\hline Public acceptance of projects & $x$ & $\checkmark$ & - & - \\
\hline \multicolumn{5}{|l|}{ Client related factors } \\
\hline History of the client (payment in the past project) & - & - & $\checkmark$ & $x$ \\
\hline Current financial condition of the client & $x$ & $\checkmark$ & - & - \\
\hline Politicians pressure on the client & - & - & $\checkmark$ & $x$ \\
\hline Business level of the client & - & - & $\checkmark$ & $x$ \\
\hline Project duration provided by the client & $x$ & $\checkmark$ & - & - \\
\hline \multicolumn{5}{|l|}{ Region related factors } \\
\hline Availability of required material in the region & - & - & $\checkmark$ & $x$ \\
\hline Availability of skilled labor & - & - & $\checkmark$ & $x$ \\
\hline Stability of the political situation in the region & $\checkmark$ & $x$ & - & - \\
\hline
\end{tabular}


The objective of this research is to explore the differences in extrinsic factors influencing the bid/no-bid decision of construction contracting firms (CCFs) having varied sizes and industrial experiences. The results of the study shed light on the various degrees of differences between small and large, and young and mature CCFs with regard to factors influencing the bid/no-bid decision of CCFs. In terms of firm size, the results revealed that small CCFs are more affected by the market related factors such as market value and number of competitors in the market and client related factors such as current financial condition of the client and project duration given by the client as compared to their larger counterparts. The importance relayed to these factors is reflective of the construction firms own standing in the market which is developed by its reputation, political ties, financial health, human capital, and adequate resources for competition. A significant finding in the current study leads to the conclusion that small CCFs are discouraged from bidding on large-scale projects, as they have limited political resources to acquire the projects.

In terms of firm experience, the results found that mature CCFs are more affected by the client related and regional connected factors as compared to the young firms. They are pressured by the government in various forms concerning to bidding. Additionally, mature CCFs are more concerned about the history and financial soundness of client as well as availability of required material and skilled labor in the market. Conversely, young CCFs are more influenced by the market related factors such as availability of similar type of projects in the market and number of competitors in the market. It is evident from the current case that in order for the construction industry to thrive and compete, there needs to be extensive reforms in the government specifically when it comes to interacting with small CCFs.

This study contributes to the previous literature by adding to the limited research work on the bid/no-bid decision of CCFs. This work provides novel insights on bid/no-bid decision making of CCFs by showing how firm size and experience is associated with their bidding decisions. Additionally, the findings of this study will help CCFs to capitalize on the key extrinsic factors influencing their bidding decision as per their respective size and experience. Lastly, the results of this study can be useful for the CCFs belonging to other regions and countries having the construction industry structure same as that of the developing country.

\section{Study limitations and future research directions}

The current research findings are to be viewed taking into account that the work is exploratory and focuses only on the construction sector of a developing country, particularly Federal and Punjab province area. Nonetheless, the findings of the current research can be applied to other developing regions and countries with caution. In future, the scholars may take into consideration a bigger sample size from other provinces as well as other developing countries in order to generalize the results across larger population. Internal factors related to the management and organization are not studied in this work. Researchers may investigate the impact of firm size and experience on internal factors influencing the bid/no-bid decision of CCFs. In addition, if a study is conducted using a longitudinal method, it may yield valuable results.

References

Abdul-Aziz, A.R., Nor Azmi, H.-A. C., Law, Y.H., \& Pengiran, D. N. (2013). Internationalization of Construction-Related Consultants: Impact of age and size. Journal of Professional Issues in Engineering Education and Practice, 139(2), 148-155. https://doi.org/10.1061/(ASCE)El.19435541.0000135

Ahmad, I. (1990). Decision-support system for modeling bid/no-bid decision problem. Journal of Construction Engineering and Management, 116(4), 595-608. https://doi.org/10.1061/(ASCE)0733-9364(1990)116:4(595)

Ahmad, Z., Thaheem, M. J., \& Maqsoom, A. (2018). Building information modeling as a risk transformer: An evolutionary insight into the project uncertainty. Automation in Construction, 92, 103-119. https://doi.org/10.1016/j.autcon.2018.03.032

Akintoye, A. S., \& Skitmore, M. (1990). A conceptual model of construction contractors' pricing strategies. In: Sixth Annual Conference, Association of Researchers in Construction Management, 1990-09-01 - 1990-09-01. https://eprints.qut.edu.au/4476/

Bageis, A., Falqi, I. I., Alshehri, A., Alsulamy, S., \& Alsahli, T. A. (2019). Behavioral differences towards internal and external factors in making the bid/no-bid decision. Civil Engineering Journal, 5(5), 1189-1196. http://dx.doi.org/10.28991/cej-2019-03091323

Bageis, A. S., \& Fortune, C. (2009). Factors affecting the bid/no bid decision in the Saudi Arabian construction contractors. Construction Management and Economics, 27(1), 53-71. https://doi.org/10.1080/01446190802596220

Bustos-Salvagno, J. (2015). Bidding behavior in the Chilean electricity market. Energy Economics, 51, $288-299$. https://doi.org/10.1016/j.eneco.2015.07.003 
Chou, J.-S., Pham, A.-D., \& Wang, H. (2013). Bidding strategy to support decision-making by integrating fuzzy AHP and regression-based simulation. Automation in Construction, 35, 517-527. https://doi.org/10.1016/j.autcon.2013.06.007

Chua, D., \& Li, D. (2000). Key factors in bid reasoning model. Journal of Construction Engineering and Management, $126(5)$, 349-357. https://doi.org/10.1061/(ASCE)0733-9364(2000)126:5(349)

Di Gregorio, D., Musteen, M., \& Thomas, D. E. (2008). International new ventures: The cross-border nexus of individuals and opportunities. Journal of World Business, 43(2), 186-196. https://doi.org/10.1016/j.jwb.2007.11.013

Dulaimi, M. F., \& Shan, H. G. (2002). The factors influencing bid mark-up decisions of large-and medium-size contractors in Singapore. Construction Management \& Economics, 20(7), 601-610. https://doi.org/10.1080/01446190210159890

Egemen, M., \& Mohamed, A. N. (2005). Different approaches of clients and consultants to contractors' qualification and selection. Journal of Civil Engineering and Management, 11(4), 267-276. https://doi.org/10.3846/13923730.2005.9636357

Egemen, M., \& Mohamed, A. N. (2007). A framework for contractors to reach strategically correct bid/no bid and mark-up size decisions. Building and Environment, 42(3), 1373-1385. https://doi.org/10.1016/j.buildenv.2005.11.016

El-Mashaleh, M. S. (2013). Empirical framework for making the bid/no-bid decision. Journal of Management in Engineering, $29(3), 200-205$. https://doi.org/10.1061/(ASCE)ME.1943-5479.0000147

Enshassi, A., Mohamed, S., \& El Karriri, A. a. (2010). Factors affecting the bid/no bid decision in the Palestinian construction industry. Journal of Financial Management of Property and Construction, 15(2), 118-142.https://doi.org/10.1108/13664381011063421

Friedman, L. (1956). A competitive-bidding strategy. Operations Research, 4(1), 104-112. https://doi.org/10.1287/opre.4.1.104

Fu, W., Drew, D. S., \& Lo, H. (2002). The effect of experience on contractors' competitiveness in recurrent bidding. Construction Management \& Economics, 20(8), 655-666.https://doi.org/10.1080/0144619022000014060

Gates, M. (1967). Bidding strategies and probabilities. Journal of the Construction Division, 93(1), 75-110. https://cedb.asce.org/CEDBsearch/record.jsp?dockey=0014684

Heravi, G., \& Mohammadian, M. (2020). Investigating cost overruns and delay in urban construction projects in Iran. International Journal of Construction Management, In Press. https://doi.org/10.1080/15623599.2019.1601394

Hill, C. (2008). International business: Competing in the global market place. Strategic Direction, 24(9). https://doi.org/10.1108/sd.2008.05624iae.001

Hwang, J.-S., \& Kim, Y.-S. (2016). A bid decision-making model in the initial bidding phase for overseas construction projects. KSCE Journal of Civil Engineering, 20(4), 1189-1200. https://doi.org/10.1007/s12205-015-0760-y

Jarkas, A. M., Mubarak, S. A., \& Kadri, C. Y. (2014). Critical factors determining bid/no bid decisions of contractors in Qatar. Journal of Management in Engineering, 30(4), 05014007. https://doi.org/10.1061/(ASCE)ME.1943-5479.0000223

Korkmaz, S., \& Messner, J. I. (2008). Competitive positioning and continuity of construction firms in international markets. Journal of Management in Engineering, 24(4), 207-216. https://doi.org/10.1061/(ASCE)0742-597X(2008)24:4(207)

Krasnokutskaya, E., \& Seim, K. (2011). Bid preference programs and participation in highway procurement auctions. American Economic Review, 101(6), 2653-2686. http://dx.doi.org/10.1257/aer.101.6.2653

Li, G., Chen, C., Zhang, G., \& Martek, I. (2020). Bid/no-bid decision factors for Chinese international contractors in international construction projects. Engineering, Construction and Architectural Management, In Press. https://doi.org/10.1108/ECAM-11-2018-0526

Low, W. W., Abdul-Rahman, H., \& Zakaria, N. (2020). Organizational culture of Malaysian international construction organizations. International Journal of Construction Management, 20(2), 105-121. https://doi.org/10.1080/15623599.2018.1484552

Lowe, D. J., \& Parvar, J. (2004). A logistic regression approach to modelling the contractor's decision to bid. Construction Management and Economics, 22(6), 643-653. https://doi.org/10.1080/01446190310001649056

$\mathrm{Ma}, \mathrm{H}$. (2011). Factors affecting the bid/no bid decision-making process of small to medium size contractors in Auckland. Report for Industry Project CONS7819, Unitec Institute of Technology, New Zealand. http:hdl.handle.net/10652/1785

Maqsoom, A., Bajwa, S., Zahoor, H., Thaheem, M. J., \& Dawood, M. (2019). Optimizing contractor's selection and bid evaluation process in construction industry: Client's perspective. Revista de la Construcción, 18(3), 445-458. http://dx.doi.org/10.7764/rdlc.18.3.445

Maqsoom, A., \& Charoenngam, C. (2014). Motives and competitive assets of Pakistani international construction contracting firms: Impact of size and international experience. Journal of Financial Management of Property and Construction, 19(2), 138-151. https://doi.org/10.1108/JFMPC09-2013-0037

Maqsoom, A., Choudhry, R. M., Umer, M., \& Mehmood, T. (2020). Influencing factors indicating time delay in construction projects: Impact of firm size and experience. International Journal of Construction Management, In Press. https://doi.org/10.1080/15623599.2019.1613206

Maqsoom, A., Farjad, M. M., Abbas, M. S., Ehtesham-Ul-Haque, M., Irfan, M., \& Malik, A. U. (2018). Strategic Factors Influencing Bid/No-Bid Decision of Pakistani Contractors. In: Chau K., Chan I., Lu W., and Webster C. (Editors). Proceedings of the 21st International Symposium on Advancement of Construction Management and Real Estate. Springer, Singapore, 1345-1353. https://doi.org/10.1007/978-981-106190-5_118

Mohanty, J. N. (1992). Reason and tradition in Indian thought: An essay on the nature of Indian philosophical thinking. Oxford: Clarendon Press; New York. https://searchworks.stanford.edu/view/2467698

Newcombe, R., Langford, D., \& Fellows, R. (1990). Construction Management. Mitchell, London. https://trove.nla.gov.au/version/45226815 
Nirab, S. (2007). Investigation into contractors' bidding decisions in Gaza Strip. Unpublished Master Thesis, Islamic University, Gaza Strip. http://hdl.handle.net/20.500.12358/19525

Ndubisi, N. O., \& Iftikhar, K. (2012). Relationship between entrepreneurship, innovation and performance: Comparing small and medium-size enterprises. Journal of Research in Marketing and Entrepreneurship, 14(2), 214-236. https://doi.org/10.1108/14715201211271429

Odusote, O., \& Fellows, R. (1992). An examination of the importance of resource considerations when contractors make project selection decisions. Construction Management and Economics, 10(2), 137-151. https://doi.org/10.1080/01446199200000013

Oyeyipo, O., Odusami, K. T., Ojelabi, R. A., \& Afolabi, A. O. (2016). Factors affecting contractors' bidding decisions for construction projects in Nigeria. Journal of Construction in Developing Countries, 21(2), 21-35. https://dx.doi.org/10.21315/jcdc2016.21.2.2

Razzaq, A., Thaheem, M. J., Maqsoom, A., \& Gabriel, H. F. (2018). Critical external risks in international joint ventures for construction industry in Pakistan. International Journal of Civil Engineering, 16(2), 189-205. https://doi.org/10.1007/s40999-016-0117-z

Ren, Z., Kwaw, P., \& Yang, F. (2012). Ghana's public procurement reform and the continuous use of the traditional procurement system: The way forward. Built Environment Project and Asset Management, 2(1), 56-69. https://doi.org/10.1108/20441241211235053

Shabbar, H., Ullah, F., Ayub, B., Thaheem, M. J., \& Gabriel, H. F. (2017). Empirical evidence of extension of time in construction projects. Journal of Legal Affairs and Dispute Resolution in Engineering and Construction, 9(3), 04517008.https://doi.org/10.1061/(ASCE)LA.1943-4170.0000217

Shash, A. A. (1993). Factors considered in tendering decisions by top UK contractors. Construction Management and Economics, 11(2), 111118.https://doi.org/10.1080/01446199300000004

Shash, A. A., \& Abdul-Hadi, N. H. (1993). The effect of contractor size on mark-up size decision in Saudi Arabia. Construction Management and Economics, 11(6), 421-429.https://doi.org/10.1080/01446199300000048

Shokri-Ghasabeh, M., \& Chileshe, N. (2016). Critical factors influencing the bid/no bid decision in the Australian construction industry. Construction Innovation, 16(2), 127-157.https://doi.org/10.1108/Cl-04-2015-0021

Skitmore, M. (2002). Predicting the probability of winning sealed bid auctions: A comparison of models. Journal of the Operational Research Society, 53(1), 47-56. https://doi.org/10.1057/palgrave.jors.2601236

Sonmez, R., \& Sözgen, B. (2017). A support vector machine method for bid/no bid decision making. Journal of Civil Engineering and Management, 23(5), 641-649. https://doi.org/10.3846/13923730.2017.1281836

Staniewski, M. W., Nowacki, R., \& Awruk, K. (2016). Entrepreneurship and innovativeness of small and medium-sized construction enterprises. International Entrepreneurship and Management Journal, 12(3), 861-877.https://doi.org/10.1007/s11365-016-0385-8

Straub, A., \& van Mossel, H. J. (2007). Contractor selection for performance-based maintenance partnerships. International Journal of Strategic Property Management, 11(2), 65-76.https://doi.org/10.1080/1648715X.2007.9637561

Ullah, F., Ayub, B., Siddiqui, S. Q., \& Thaheem, M. J. (2016). A review of public-private partnership: Critical factors of concession period. Journal of Financial Management of Property and Construction, 21(3), 269-300.https://doi.org/10.1108/JFMPC-02-2016-0011

Wanous, M., Boussabaine, H. A., \& Lewis, J. (2003). A neural network bid/no bid model: The case for contractors in Syria. Construction Management and Economics, 21(7), 737-744.https://doi.org/10.1080/0144619032000093323

Zhao, X., Hwang, B.-G., \& Phng, W. (2014). Construction project risk management in Singapore: Resources, effectiveness, impact, and understanding. KSCE Journal of Civil Engineering, 18(1), 27-36.https://doi.org/10.1007/s12205-014-0045-x

Zawawi, M. I., Kulatunga, U., \& Thayaparan, M. (2016). Malaysian experience with public-private partnership (PPP): Managing unsolicited proposal. Built Environment Project and Asset Management, 6(5), 508-520.https://doi.org/10.1108/BEPAM-10-2015-0059 